\title{
The Obstacles of Legal Structures on State Administrative Courts in Resolving the Permits of Forest Utilization
}

\author{
Francisca Romana Harjiyatni ${ }^{1 \mathrm{a}}$, Ishviati Joenaini Koenti ${ }^{1 \mathrm{~b}}$ \\ ${ }^{1}$ Faculty of Law, University of Janabadra Yogyakarta, Indonesia \\ a sisca.rh@gmail.com
}

\begin{abstract}
The State Administrative Court is an institution that has the function of resolving state administrative disputes. One of the disputes settled by the State Administrative Court is a dispute on forest use permits. In solving the dispute on the permit of forest utilization of the State Administrative Court found several obstacles, so the State Administration Court is unable to provide optimal legal protection for justice seekers. The first obstacle is the understanding of judges who are still lacking on forestry issues. The second obstacle is that the State Administration Court has not yet existed in every region in Indonesia, so that justice seekers have difficulties in accessing justice because of the existence of the State Administrative Court which is far from their area. Efforts to overcome these obstacles: first, enhancing the ability of judges to solve special cases related to the environment and forestry and holding special ad hoc judges to deal with cases related to environmental and forest disputes; secondly, immediately establish a State Administrative Court in an area where the potential disputes for forest utilization permit are quite large.
\end{abstract}

Keywords-State Administrative Court; dispute; forest use permit

\section{INTRODUCTION}

The judiciary played an important role in protecting forests[1]. The State Administrative Court has the authority / competence to examine, judge and decide upon state administrative disputes, one of which is environmental and forestry dispute'. Resolving disputes in the environmental and forestry fields often result in a decision that is perceived as lacking justice for the justice seekers as well as in the preservation of the environment. Similarly, the settlement of environmental and forestry disputes pursued through the State Administrative Court.

There is a goal to be achieved in dispute resolution in the Administrative Court of Justice namely legal protection for justice seekers both procedural justice and substantial justice. To be able to provide a fair legal protection [2], of course it takes effort to achieve balance in realizing procedural justice and substantial justice in the settlement of cases, because these two things affect each other. It is in line with the statements by Cekli Setya Pratiwi as follows, "Substantial justice will be in vain if procedural justice is ignored. Substantial justice will also be difficult to achieve if procedural justice is ignored. Therefore procedural justice is just as important as substantial justice. ". [3]

The procedures for dispute settlement in the Administrative Court have been arranged in such a way so it is hoped that the settlement of disputes in the Administrative Court can fulfil procedural justice. Like substantial justice, the settlement of disputes in the Administrative Court has been prepared special judges who master the knowledge related to the substance of the Administrative Court dispute. However, in practice, dispute resolution in the State Administrative Court specifically in environmental or forestry disputes has not provided optimal legal protection for justice seekers or for the preservation of the environment and forests. It is due to the legal institutional constraints that sofia R. hirakuri mentions as a deficient legal structure [4], which causes optimal legal protection cannot be realized in the settlement of environmental or forestry disputes in the State Administrative Court.

In environmental and forestry disputes, substantial justice to be achieved is not only a substantial justice for justice seekers but also for the protection of forests and the environment. Thus, in cases of environment or forestry, the State Administrative Court is also able to contribute to the realization of environmental sustainability and forestry through its decisions.

In this paper, it will discuss further about the legal institutional constraints that cause the State Administrative Court has not been able to provide optimal legal protection for justice seekers as well as environmental and forest protection.

\section{RESEARCH METHOD}

This study is a doctrinal study, which uses secondary data consisting of legal materials covering primary, secondary, and tertiary legal materials. The legal materials obtained in the study will be collected, grouped according to their respective variables, for the next to be analysed qualitative juridical. The approach method used in analyzing the legal materials is the statue approach and the conceptual approach. The results of the study are presented in an analytical prescriptive form. 


\section{RESULT AND DISCUSSION}

\section{A. Institutional Obstacles}

\section{Lack of Knowledge of Judges in Forestry and Forest Sustainability}

In addition to procedural justice, the settlement of cases also require substantial justice. According to Bagir Manan referred to as substantive justice that is related to the content of justice itself [5], including in the judge's decision. In cases involving the living and forestry environment, judges should be able to accommodate justice for justice seekers and for the environment. In such cases, the judge cannot avoid the obligation to decide cases by considering the aspects of environmental or forest sustainability. However this is an obstacle due to a lack of judge understanding of the substance of the forest and its sustainability.

Constraints on the judge's lack of understanding of the substance of the forest and its preservation, can be seen from the decisions of the State Administrative Tribunal which decide upon the State Administrative Dispute whose object is forest utilization permit. In the State Administrative Dispute concerning the utilization permits decided by the State Administrative Court, most are less concerned with the principle of "sustainable development" and the principle of "sustainable forest management", so that the State Administrative Court decisions on forest utilization permits have little consideration from aspects of forest protection or conservation of forests, as well as legal protection of the people who live or live in the forest.

It is due to environmental problems in general and forest sustainability in particular is a material that not every judge controls well. The judge's understanding of forests and their sustainability is lack, thus it causes the judgment less consideration of forest sustainability aspects. To address the judges' understanding of the environment in general and forest sustainability in particular, the Ministry of the Environment in collaboration with the Supreme Court provides training on environmental materials to judges from Administrative Court at first level to Supreme Court Justices. For judges who pass the certificate. Certification training is conducted from 2011 .

In the training, there are some materials related to the forestry field, which include:

a. Procedural and Substantial Aspects of Procedural Law of State Administration of Environment and Natural Resources.

b. Scientific and Legal Evidence: Aspects of Environmental Damage Due to Illegal Logging.

c. Scientific and Legal Evidence: Aspects of Environmental Destruction Due to Forest Fire and Land.

By providing environmental certification training to judge within the Supreme Court including to the judges of the State Administrative Court, it is expected that the State Administrative Court may perform its functions in resolving the State Administrative Dispute whose object is the permit of forest utilization to the maximum. With an understanding of the environment in general and the forest in particular better, it is expected that the judge can examine the State Administrative Dispute whose object is the permit of forest utilization that covers the substance from the forest sustainability aspect. In contrast to the judges' decisions in relation to forestry issues, which have put forward the formal procedural aspect, and do not touch the substantial aspects.

\section{Unfulfilled the State Administrative Court Institutions in Each District}

The dispute settlement by the administrative court requires a fair settlement process called procedural justice [6]. Wojciech Sadurski says that procedural justice is the process of getting justice from the beginning to get a decision [7]. The fair process should be set forth in the form of written rules, then implemented in the practice of settlement of cases. In a fair process, it is not implemented as stipulated in written regulations, it can be said that procedural justice is not achieved.

This is in line with those presented in the following opinion. Regarding Lon Fuller's view of procedural justice, Donald H.J. Herman says, "Fuller sets out eight procedural requirements for just law: 1) the existence of general rules, 2) promulgation, 3) prospectivity, 4) clarity, 5) consistency, 6) the defence of impossibility , 7) constancy through time, and 8) "congruence between official action and declared rules"[8]. From these opinions indicate that one of the procedural requirements for fair law is the appropriateness between practice and written rules.

In the legal institution of the Administrative Court, there is a discrepancy between written rules and practices. Article 6 paragraph (1) of The Act no. 5 of 1986 states that "Administrative Courts are domiciled in the municipality or district capitals, and their jurisdiction covers the municipalities or districts", but in practice not every regency / city has the State Administrative Court. This is a constraint of the Administrative Court in exercising its authority to examine and decide upon the cases. There should be a State Administrative Court at the first level every regency/city, and each province has a State Administrative High Court at the appellate level, however this has not been fulfilled in accordance with the required provisions.

At that time, the Law No. 5 of 1986 shall be effective, based on Presidential Decree no. 52 of 1990 established several State Administrative Courts which include:

a. Medan State Administrative Court whose jurisdiction covers North Sumatra, Special Region of Aceh, West Sumatera, and Riau.

b. Palembang State Administrative Court whose jurisdiction covers South Sumatra, Jambi, Bengkulu, Lampung.

c. Jakarta State Administrative Court whose jurisdiction covers DKI, West Java, West Kalimantan, South Kalimantan, Central Kalimantan and East Kalimantan.

d. Surabaya State Administrative Court whose jurisdiction covers East Java, Central Java, and Yogyakarta. 
e. Ujung Pandang State Administrative Court whose jurisdiction covers South Sulawesi, Southeast Sulawesi, Central Sulawesi, North Sulawesi, Bali and West Nusa Tenggara, East Nusa Tenggara, Maluku, East Timor and Irian Jaya.

With the Law No. 10 Year 1990 established 3 (three) State Administrative High Court covering:

a. The Jakarta State Administrative High Court whose jurisdiction covers: DKI Jakarta, West Java, Central Java, Special Region of Yogyakarta, East Java, West Kalimantan, South Kalimantan, Central Kalimantan and East Kalimantan.

b. Medan State Administrative High Court whose jurisdiction covers: North Sumatra, Special Region of Aceh, West Sumatera, Riau, South Sumatera, Jambi, Bengkulu, Lampung.

c. Ujung Pandang State Administrative High Court whose jurisdiction covers: North Sulawesi, South Sulawesi, Central Sulawesi, Southeast Sulawesi, Maluku, Bali, West Nusa Tenggara, East Nusa Tenggara, East Timor and Irian Jaya.

The establishment of the State Administrative Court and the State Administrative High Court have not fulfilled the provisions of Constitution no. 5 of 1986. Article 6 of the Law No. 5 of 1986 states that:

(1) State administrative courts are located in the municipality or district capitals, and their jurisdiction covers the municipal or district territory.

(2) The state administrative high court is domiciled in the provincial capital, and its jurisdiction covers the province.

The background to the non-compliance with this provision is that there have not been many state administrative disputes submitted to the State Administrative Court, even the state administrative Courts in some areas have not had a case in the first year since the Law No. 5 of 1986 is effective. Elucidation of Law no. 5 of 1986 states that the establishment of State Administrative Court and State Administrative High Court will be implemented gradually with attention to several factors both technical and non-technical.

Currently there are 28 (twenty eight) State Administrative Court and 4 (four) State Administrative High Courts covering the State Administrative High Court of Jakarta, the State Administrative High Court of Surabaya, the State Administrative High Court of Medan and the State Administrative Court of Makassar. The legal areas of Jakarta State Administrative High Court include Serang, DKI Jakarta, West Java, Central Kalimantan, South Kalimantan, East Kalimantan, West Kalimantan. It shows that the existence of the Courts in each district / city and the State Administrative High Court in each province has not been met.

The limited number of State Administrative Courts become a separate constraint within the Administrative Court providing legal protection for justice seekers. The non-fulfillment of the State Administrative Court in each regency / city and the State Administrative High Court in each province may impose an obstacle for a person or legal entity harmed by administrative decision to be able to claim to the Administrative Court, if there is no State Administrative Court or State Administrative High Court in handling the dispute. It causes the justice seeker to take a long time to be able to fight for rights, which of course will add weight in the fight for their rights in terms of time, energy and cost. For those who cannot afford this, they are reluctant to file a lawsuit to the Administrative Court and tend to be resigned to such circumstances.

Regarding the existence and number of Administrative Court Courts in Indonesia, Adriaan Bedner said,

The courts are difficult to access by plaintiffs. The extent of territory covered by the authority of a single State Administrative Court may be seen as a setback in terms of legal protection for citizens, rather than a system of lawsuits against rulers that existed prior to 1991, since the number of State Administrative Courts is only onequarter of the number of district courts available in each district. [9]

Before the Law No. 5 of 1986 is effective, application of a lawsuit against the government submitted to a civil court in a civil case, at that time the plaintiff had the ease to claim to the court because in every district / municipality is available a district court. After the establishment of the Administrative Court, the lawsuit against the government relating to administrative decision is submitted to the State Administrative Court, but this change makes the plaintiffs' access to court more difficult, since the State Administrative Court has not yet been fulfilled in each district/city. Whereas the establishment of State Administrative Court is intended to be able to provide maximum legal protection to the justice seekers who are harmed by the authorities through judicial institutions. The legal protection guarantee for justice seekers has become unmet because of the difficulty of plaintiffs in accessing the courts for legal protection.

\section{B. The Efforts to Solve The Institutional Obstacles of State Administrative Court \\ In carrying out its duties and authorities to examine,} hear and decide upon the State Administrative Dispute, the Administrative Court shall not merely provide legal protection to justice seekers as individuals but also take into account the wider interests of the community. In a State Administrative Dispute whose object is a forest utilization permit, there is a wider interest other than individual interests such as the interest of the permit holder or the permit applicant, the interests of the people living in the forest surrounding which depend on the forest resources, and the importance of forest sustainability itself. In the case examination practice in the State Administrative Court that has the object of disputes of forest utilization permit, there is a tendency of administrative court decision to protect only the interests of the justice seeker or plaintiff as an individual, but less attention to other interests in society such as the interests of forest-dependent people and the interests of forest sustainability. Such decisions usually leave various problems in the community such as conflicts of interest in the use of forests and the occurrence of forest destruction. 
Such a thing can happen because the judge State Administrative tends to lack understanding of the issues in the field of forestry and its sustainability. To overcome this, it is possible to establish an ad hoc judge who specializes in forestry law. The basis for the establishment of an ad hoc judge is Article 9A of the Law No. 51 of 2009 which states as follows:

(1) In the environment of the Administrative Court may be established a special court regulated by law.

(2) Special Court may be appointed an ad hoc judge to examine, hear, and decide cases that require expertise and experience in a particular field and within a certain period of time.

(3) Provisions on the terms and procedures for the appointment and dismissal and allowance of ad hoc judges are stipulated in the provisions of laws and regulations.

The provision mentioned above opens the opportunity for the establishment of special courts within the State Administrative Court. This is not surprising, given that the Administrative Court has the duty and authority to examine the State Administrative Dispute whose object of disputes covers various kinds of administrative decisions, such as administrative decision in the field of land, mining, environment, and forestry. Each administrative decision has different characteristics in accordance with the objective of issuing the decision.

In certain cases such as State Administrative disputes in the environmental and forestry sectors, ad hoc judges are urgently needed to control the career judges in examining and adjudicating cases, so that judges are completely independent in examining, deciding and resolving State Administrative disputes, it costs for ad hoc judges cheaper than career judges.

Cases in the environment, especially forestry, typically involve large capital owners who can have a strong influence on the independence of the courts / judges, so that ad hoc judges are expected to control judges to work objectively and with specific expertise of ad hoc judges can help to realize decisions that provide legal protection for justice seekers and accommodate the interests of forest sustainability. In Netherlands the cost of ad hoc judges is cheaper, as ad hoc judges work and are paid incidentally instead of being paid monthly, this is different from Indonesia where an ad hoc judge is employed as a permanent employee and has the same rights and duties as a judge career.

Administrative decision in forestry sector, especially forest utilization permit have different function and purpose. Forest utilization permit has the function of controlling so that activities in exploiting forest do not cause damage to forest, so in implementing forest utilization permit is accompanied by obligation for license holder to maintain the forest well. The purpose of the issue of forest utilization permit is to realize the maximum utilization of forests and realize the sustainability of forests, the realization of this goal is intended to arrive at the goal of realizing a just and prosperous society according to the state goals contained in the Preamble of the 1945 Constitution. In carrying out its duties and authority, State Administrative Court Judges should understand the function and purpose of the forest utilization permit itself, so as the judges can make a judgment which provides protection for justice seekers without prejudice to other interests within the community in forest utilization. In order to make this happen, an ad hoc judge is required to have specific expertise in the field of forestry law in particular or environmental law in general.

Ad hoc comes from Latin, in English called "for this", "for this special purpose" [10] which means it is for a special purpose. Ad hoc is a way of being used for specific problems or tasks, and is not intended to be tailored to other purposes. An ad hoc judge is a judge appointed from outside a career judge who meets professional, dedicated and high integrity requirements, living the ideals of a justice law and welfare state, understanding and respecting human rights and basic human rights. A State Administrative dispute whose object is a forest utilization permit is a specific problem in the field of State Administrative Court. The dispute concerns issues relating to the broader interest that is related to the function of the forest for the community, either the people who depend the forest resources directly for their life and the world community.

In relation to the special judge handling cases with environmental aspects, it is issued the Decree of the Chief of the Supreme Court of the Republic of Indonesia Number 134 / KMA / SK / IX / 2011 concerning Certification of Environmental Judges. One of the reasons for the issue of the Supreme Court Decree is that "The quality of the environment and natural resources is declining and threatening the survival of human life, other living things and ecosystems due to ineffective enforcement of natural environment and natural resources". On that basis, Article 2 of the Supreme Court Decree provides that "Environmental Cases shall be judged by a certified environmental judge and appointed by the Chief of the Supreme Court". The meaning of environmental matters shall be regulated in Article of the Decree of the Supreme Court as follows:

a. Violation of administrative regulations in the field of environmental protection and management, including but not limited to regulations in the fields of forestry, plantation, mining, coastal and marine, spatial, water resources, energy, industry and / or natural resource conservation;

b. Violations of civil and criminal provisions in the field of environmental protection and management, including but not limited to regulations in the fields of forestry, plantation, mining, coastal and marine, spatial, water resources, energy, industry and / or natural resource conservation.

Based on the above provisions indicates that, in the case of the environment, including in the field of forestry, a special environmental certified judge is required to make the settlement of the case more effective and provide environmental justice. Article 6 Paragraph (1) of the Supreme Court Decree states that, what is meant by an environmental judge is An environmental judge is a judge 
who has been appointed by the Decree of the Chief of the Supreme Court and meets the following criteria: a. Administrative requirements; b. Competency requirements; c. Attend training; d. Declared passed by the Selection Team. The terms of competence as referred to in Article 6 paragraph (1) mentioned above are as follows:

a. Able to understand the norms of national and international environmental law;

b. Able to implement the law as an instrument in judging environmental cases;

c. Able to make legal discovery (rechtsvinding) to realize environmental justice; and

d. Able to implement procedural law in judging environmental cases.

Based on the above matters indicate that, the judges in solving the case in the field of environment including forestry must be active to realize environmental justice, this is because the provisions on environmental judges is also applicable in the Administrative Court. Article 5 Paragraph (2) of the Decree of the Supreme Court declares that, "An environmental judge within the jurisdiction of general and state administrative courts is authorized to adjudicate environmental cases in accordance with their powers". The provisions indicate that environmental cases in the State Administrative Court is handled by an environmental judge who has the authority to be active in conducting legal discovery to bring about environmental justice.

In the event that a certain State Administrative Court does not have an environmental judge, the appointment of environmental judges in temporary judge detachment (detasering) shall be made. Article 21 of the Decision of the Supreme Court stipulates that,

(1) Environmental cases at the first and the appellate courts within the general court and state administrative courts shall be tried by a panel of judges whose chairperson is an environmental judge.

(2) In the case of a court of first instance in the general court and the state administrative court there is no environmental judge, the appellate court chairman shall appoint an environmental judge in his or her territory in temporary judge detachment (detasering).

(3) In the case of a court of appeal in the general court and the state administrative court there is no environmental judge, the Chief of the Supreme Court shall appoint an environmental judge in a temporary judge detachment (detasering) manner.

(4) In the case of an area of appellate court there is no first-level environmental judge, the Chief of the Supreme Court shall appoint an environmental judge in upon the proposal of the Chief of the appellate court.

Environmental cases must be judged by environmental judges in first instance and appellate courts, both within the general court and the Administrative Court. Environmental judges are still few in number today, so in the case of the court there is no environmental judge. The Chief of the Supreme Court appoints environmental judges by temporary judge detachment (detasering). Article 1 sub-article 3 of the Supreme Court decree states, "Temporary judge detachment (detasering) is the assignment of judges for a certain period of time in the handling of environmental cases outside the jurisdiction where the judge is in charge".

The provisions of this temporary judge detachment (detasering) cannot be implemented properly, because the number of environmental judges is few. Many cases that have aspects of the environment including forestry are tried by judges who have not certified environment. Article 27 of Transitional Provisions of The Supreme Court Decree declares that "In the absence of a certified environmental judge, environmental cases are examined, tried and decided by the General Courts or State Administrative Courts in accordance with applicable laws and regulations". The provision provides opportunities for certain environmental cases to be examined without an environmental judge.

Decree of the Chief of the Supreme Court of the Republic of Indonesia Number 134 / KMA / SK / IX / 2011 does not close to the birth of an ad hoc judge whose specialization is in the field of forestry. The case of forest utilization permits is a case in forestry which is in certain respects different from other environmental fields, so that the existence of ad hoc judges is still required in cases where the object of forest utilization permits. An environmental judge is a career judge, the existence of a career judge may be controlled by an ad hoc judge so that it can resolve the case of forest utilization permit that provides justice for the community and sustainability, so in this case an ad hoc judge is still required even if there has been an environmental judge.

The existence of an environmental judge will be useless in the event that the State Administrative Court is confined with a formalistic procedural rechtmatigheidstoetsing authority. Such authority makes the judge unable to reach substantial issues concerning forests and their preservation. The existence of environmental judges becomes useless, in the case of the principle of sustainable development is not used as a reviewing tool by the judge in resolving the dispute of forest utilization permit. Judges' decisions that accommodate the interests of forest conservation are necessary, given the essential functions of forests for the life and welfare of mankind.

With regard to sustainable development, Eduardo Silva said that:

For policy and programmatic purposes, development economists have broken the concept of sustainable development down into three interrelated components: a healthy, growing economy (which may necessitate structural adjustment); a commitment to social equity (or meeting basic needs); and protection of the environment. This definition raises two immediate difficulties. First, the terms are too general: as a result. Careful attention must be paid to their specific content as this will heavily colour policy prescriptions. Second, fulfilling all three terms, no matter how defined, is problematic because of inherent distributional - and therefore political - tensions between them. [11]

Economic development outlines the concept of sustainable development into three interconnected 
components of healthy economic growth, commitment to social interests, and protection of the environment. This concept raises two difficulties: first, the term is too general so serious attention to accommodate these three components in carrying out development; second to fulfill these three components is difficult because there is political tension between the three. Rapid economic growth will usually sacrifice the interests of environmental conservation and can also lead to conflicts within the community. Economic development that takes into account the interests of the environment as well as the interests of the community will face barriers to gain the maximum profit, so business actors tend to strive to meet the formal requirements to be able to run its activities but in the implementation of environmental conservation commitments and interests of the community are often ignored.

It also occurs the use of forests for various purposes. Business actors tend to try to meet the existing formal requirements, but the implementation of their activities tends to ignore the interests of forest conservation and the interests of the community. In cases where forest-related permits are resolved through the Administrative Court, the State Administrative judge should also assess the case from the forest conservation aspect of the wider community interest. In fact the State Administrative Judge tends to support the implementation of development in the field of forestry which is only concerned with economic aspects. It is caused by the lack of knowledge of judges in forestry and its sustainability. Demin Yang said, "Different understandings of legal protection benefits will lead to different evaluations of the provisions of judicial interpretation"[12] An ad hoc judge is required to have expertise or experience in the field of forestry, so that the Administrative Court can make Decisions that accommodate the economic interests, the interests of the community, and the interests of preserving the forest environment.

\section{CONCLUSION}

The State Administrative Court has obstacles in resolving state administrative disputes, especially forestry or environmental disputes. It is due to the obstacles such as a lack of judge's knowledge of forest or environmental substance. So that the judgments made by judges are less likely to contribute to conservation of forests or the environment. It is also caused by the difficulty of accessing justice through the courts because some regions in Indonesia have not been yet a State Administrative Court. Therefore, it is urgent to establish an Ad hoc judge who has the special knowledge and expertise to handle forestry or environmental cases and immediately establish a State Administrative Court in all regions of Indonesia. Thus the struggle for justice including environmental justice will become easier.

\section{REFERENCES}

[1] Madhuri Parikh, "The Forest Conservation in India and the Role of Indian Supreme Court : A Critical Analysis", IOSR Journal Of Humanities And Social Science (IOSRJHSS), Volume 13, Issue 4 (Jul-Aug. 2013), p. 58

[2] Asmuni, et.al., "Implementation Suspension of State Administrative Decision by the State Administrative Court" Academic Research International, Vol. 5(3) May 2014, p. 299.

[3] Sofia R. Hirakuri, "Can Law Save the Forest?", Center of International Forestry Research, Bogor, 2003, p. 25.

[4] Cekli Setya Pratiwi, "Kegagalan Mewujudkan Keadilan Prosedural Dan Substansial Dalam Putusan Hakim Tinggi Perkara Tindak Pidana Psikotropika Nomor: 25/Pid/B/2010/Pt Sby" (Failure to Realize Procedural and Substantial Justice in the Decision of the High Judge in the Case of Psychotropic Crimes Number: 25 / Pid / B / 2010 / Pt Sby), Jurnal Humanity, Volume 9, Nomor 1, Maret 2013, p. 172

[5] Bagir Manan, 2005, "Sistem Peradilan Berwibawa (Suatu Pencarian)" (Prestigious Judicial System (A Prospecting), FH UII Press, Yogyakarta, p.12.

[6] Tom R. Tyler, dan E. AllandLind, 2002, "Prosedural Justice", Joseph Sanders dan V. Lee Hamilton, Handbook of Justice Research in Law, Kluwer Academic Publishers,New York, Boston, Dordrecht, London, Moscow, p. 65.

[7] Wojciech, Sadurski, Wojciech, 1985, “Giving Desert Its Due: Social Justice and Legal Theory", D. Reidel Publishing Company, Dordrecht, p. 49.

[8] Donald H. J. Hermann, "The Fallacy of Legal Procedure as Predominant over Substantive Justice: A Critique of "The Rule ofLaw" in John Rawls' A Theory of Justice", De Paul Law Review, Volume 23 Issue 4 Summer 1974, p. 1411.

[9] Adriaan Bedner, 2010, "Peradilan Tata Usaha Negara di Indonesia" (Administrative Court in Indonesiaa), Huma, Jakarta, Van Vollen Institute, Leiden University, KITLV, Jakarta, pp. 346-347.

[10] Henry Campbell Black, 1990, "Black's Law Dictionary", Sixth Edition, West Publishing Co, St. Paul Minn, p. 41.

[11] Eduardo Silva, "Thinking Politically about Sustainable Development in the Tropical Forests of Latin America", Development and Change, Vol. 25 (1994). 697-721, Blackwell Publishers, 108 Cowley Rd, Oxford OX4 IJF, UK.699.

[12] Demin Yang, "Study on Criminal Response Dilemma of China's Environmental Pollution Crime in the Context of Risk Society", Advances in Social Science, Education and Humanities Research, volume 233, Atlantis Press, p. 1418. 